\title{
Bone Morphogenetic Protein Coating on Titanium Implant Surface: a Systematic Review
}

\author{
Haim Haimov ${ }^{1}$, Natali Yosupov ${ }^{1}$, Ginnady Pinchasov ${ }^{1}$, Gintaras Juodzbalys ${ }^{1}$ \\ ${ }^{1}$ Department of Oral and Maxillofacial Surgery, Lithuanian University of Health Sciences, Kaunas, Lithuania.
}

\author{
Corresponding Author: \\ Haim Haimov \\ Harari Haim 11, 5824556, Holon \\ Israel \\ Phone: +37066369235 \\ Fax: +97236820474 \\ E-mail: haimha1991@gmail.com
}

\section{ABSTRACT}

Objectives: The purpose of the study is to systematically review the osseointegration process improvement by bone morphogenetic protein coating on titanium implant surface.

Material and Methods: An electronic literature search was conducted through the MEDLINE (PubMed) and EMBASE databases. The search was restricted for articles published during the last 10 years from October 2006 to September 2016 and articles were limited to English language.

Results: A total of 41 articles were reviewed, and 8 of the most relevant articles that are suitable to the criteria were selected. Articles were analysed regarding concentration of bone morphogenetic protein (BMP), delivery systems, adverse reactions and the influence of the BMP on the bone and peri-implant surface in vivo. Finally, the present data included 340 implants and 236 models.

Conclusions: It's clearly shown from most of the examined studies that bone morphogenetic protein increases bone regeneration. Further studies should be done in order to induce and sustain bone formation activity. Osteogenic agent should be gradually liberated and not rapidly released with priority to three-dimension reservoir (incorporated) titanium implant surface in order to avoid following severe side effects: inflammation, bleeding, haematoma, oedema, erythema, and graft failure.

Keywords: bone morphogenetic protein; dental prosthesis implantation; osseointegration; surface-coated materials; surface properties.

Accepted for publication: 28 June 2017

To cite this article:

Haimov H, Yosupov N, Pinchasov G, Juodzbalys G.

Bone Morphogenetic Protein Coating on Titanium Implant Surface: a Systematic Review

J Oral Maxillofac Res 2017;8(2):e1

URL: http://www.ejomr.org/JOMR/archives/2017/2/e1/v8n2e1.pdf

doi: $10.5037 /$ jomr.2017.8201 


\section{INTRODUCTION}

Currently, implantation is a daily routine especially in dental field. Endosseous dental implants are the ideal replacements for missing teeth. They give to the patient the opportunity to restore its masticatory function, improve mobility and alleviate pain. Dental implants are now often implanted immediately after tooth extraction, which, by forestalling the mechanical loading phase, necessitates for earlier establishment of physical stability via implant osseointegration [1].

However, osseointegration is often compromised in a large bone defect area $[\underline{2}, \underline{3}]$. Usages of biocompatible materials for micro as well as macro implants have greatly increased implantation success rates. In the dental implantation field, titanium (Ti) implants are most popular due to their excellent mechanical properties, biocompatibility, chemical stability, low toxicity, bioactivity and great corrosion resistance [4-6]. Yet, Ti implants cannot overcome poor bone quality or quantity conditions and results in poor healing as well as regeneration abilities [7]. Another drawback of Ti implants is the long fixation time of the bone to the implant that usually takes several months for healing [ $\underline{8}]$. Bone is a dynamic organ, it resorbs and forms steadily in the human body, and the massiveness of bone resorption over the years requires bone augmentation which plays a crucial role in compensation of damaged sites $[\underline{9}, \underline{10}]$. Nowadays, osseous autograft considers the gold standard for large bony defects repair, even though the amount of the bone is restricted [11].

In the current literature, different agents were suggested for bone stimulation as; hydroxyapatite (HA), type-I collagen (CO) and bone morphogenetic protein (BMP). CO found to be a major component in bone composition, causing increases in tissue vascularization, decreases in inflammation by decelerating macrophage and osteoclast activity. However, CO coating alone is not sufficient to accelerate the differentiation of osteoblasts. HA which is a main inorganic component in bone tissue, serves also as bone graft material, even though its usage regarding the long term survival is controversial [12].

BMPs belong to transforming growth factor beta (TGF- $\beta$ ) superfamily, are biological factors which play major roles in the osteogenesis process [11], by regulation of osteogenic cells and differentiation of bone mesenchymal stem cells (MSCs) []]. BMPs are widely used as an additive for bone graft material; its addition contributes for bone to implant contact (BIC) [12].
In various studies the usage of BMP reported to improve and enhance osteogenesis process, osteoblasts activity, chondroblast activity and osseointegration after dental implantation. From the variety of BMPs, BMP-2 and BMP-7 derivatives showed to be the most effective for inducing bone morphogenesis [13]. Moreover, recombinant human BMP-2 has been available for therapeutic use given its rapid ability to trigger the differentiation of osteoblasts [14].

BMP-2 has an important role in regulating the osteogenic differentiation of MSCs and also in the response of bony and tissue formation [15]. BMP-7 also known as osteogenic protein-I which plays a major role in transformation of MSCs into bone and cartilage [11].

Preclinical and clinical studies have shown that local application of BMP-2 and BMP-7 can promote and perform cellular differentiation that raise the potential for bone repair in variety of situations including bony defects, non-union fractures, extraction sockets and osseointegration $[\underline{1}, \underline{15}]$.

Even though supra-physiological amount of BMP is required for successful bone healing, high doses can result in rapid and inefficient BMP escape from its carrier which in turn can cause complications as: ectopic bone formation, excessive bone resorption and formation of malignant processes, which was not specified in the study. The same study proved that a prolonged presence of BMP-2 within the defected site will result in increased amount of bone formation. It was also found that prolong presence of BMP-2 within the defected site will lower the amount of the BMP required for sufficient effect. The applications of BMPs on Ti surface can improve the osseointegration of dental implants and shorten the time period for implant integration [15].

The purpose of the present review is to investigate the osseointegration process improvement by bone morphogenetic protein coating on titanium implant surface.

\section{MATERIAL AND METHODS Protocol and registration}

Analysis and inclusion criteria methods were specified in advance and documented in a protocol. The review is registered in an international prospective register of systematic reviews 'PROSPERO' [16]. The protocol registration number: CRD42016051836.

The protocol can be assessed:

https://www.crd.york.ac.uk/prospero/display record. asp?ID $=$ CRD42016051836 


\section{Focus question}

The following focus questions were developed according to the data extracted from the current literature:

1. Does osseointegration process of $\mathrm{Ti}$ dental implant can be enhanced with administration of BMP? What kind of side effects it may develop?

2. What is the most recommended delivery method for BMP in order to accelerate osseointegration and in the same time avoid adverse effect?

\section{Types of publication}

The review included case reports, case reviews, and retrospective and prospective studies that were published in vivo in the English language. Excluded were articles in non-English language and abstracts lacking full text.

\section{Types of studies}

The review included any experimental model in vivo.

\section{Information sources}

The information sources were the MEDLINE (PubMed) database and EMBASE databases.

\section{Population}

Studies in vivo included healthy animals without systemic diseases or immunological disorders. The animals underwent BMPs treatment.

\section{Literature search strategy}

According to the PRISMA guidelines [17] an electronic search was conducted using MEDLINE (PubMed) database and EMBASE databases, in order to locate articles concerning the efficacy of BMP coated titanium implants' surface on implant osseointegration.

The Keywords used for the search included: (bone morphogenetic protein") and ((("surface-coated materials") OR ("osseointegration") OR ("dental prosthesis implantation") OR ("surface properties"). The search was restricted to English language. Articles published from October 1, 2006 to September 2016 were searched.

\section{Inclusion and exclusion criteria Inclusion criteria for the selection}

The full text articles with possible relevance were assessed with the following inclusion criteria:

- Clinical article on experimental model.

- Treatment had to be completed on healthy animals without systemic diseases and immunological disorders.

- Studies involving at least 3 models. If less so statistically irrelevant.

- Studies involving diagnostic parameter and/or clinical, histological, histomorphometrical, push out test and/or radiological.

- Minimum follow-up of 3 weeks post operation.

\section{Exclusion criteria for the selection}

- Studies that included unclear data, with authors who could not be contacted for any reason.

- Not enough information regarding selected topic.

- Articles irrelevant to the study of BMP coating Ti implants' surface and its relation to implants osseointegration.

\section{Sequential search strategy}

The selected articles were subjected independently to clear inclusion and exclusion criteria by 3 reviewers as follows. The three reviewers resolved differences obstacles through discussion, consulting a third party who was an experienced senior reviewer. Following the initial literature search, all articles were chosen according title relevancy, considering the exclusion criteria. Following, studies were excluded based on irrelevant data obtained from the abstracts. The final stage of screening involved reading the full texts and confirming each study's eligibility based on the inclusion criteria.

\section{Data extraction}

The data were independently extracted from studies in the form of variables, according to the aims and themes of the present review, as listed onwards.

\section{Data items}

Data were collected from the included articles and arranged in the following fields:

- "Author/Year" - revealed the author and year of publication.

- "Model investigated"- indicates the model which was examined.

- "Carriage mode" - described the type of delivery mode.

- "BMP type"- describes the tissue BMPs have been used. 
- "Bone formation after " $n$ " week" - indicates the bone formation follow-up after " $n$ " week, while " $n$ " indicates number of weeks.

- "Evaluation method" - methods which evaluate the amount of new bone formed.

\section{Risk of bias across studies}

To assess the quality of the studies and to identify papers with intrinsic flaws that could affect the cumulative evidence. Cochrane collaboration bias summary for potential bias was used [18].

Risk of bias assessment parameters:

- Random sequence generation (-/+/?);

- Allocation concealment (-/+/?);

- Blinding of participant's and personnel (-/+/?);
- $\quad$ Blinding of outcomes assessment (-/+/?);

- Incomplete outcome data (-/+/?);

- $\quad$ Selective reporting (-/+/?).

\section{RESULTS \\ Study selection}

The search delivered 225 search results, from which 41 abstracts were reviewed (Figure 1). A total of 41 articles were ultimately reviewed in full. Preliminary exclusion was made by the title and its relevancy and later by abstract relevancy. Finally, studies which did not meet the inclusion criteria were filtered. Eighth studies met the inclusion criteria and the present data was included on 340 implants and 236 models.

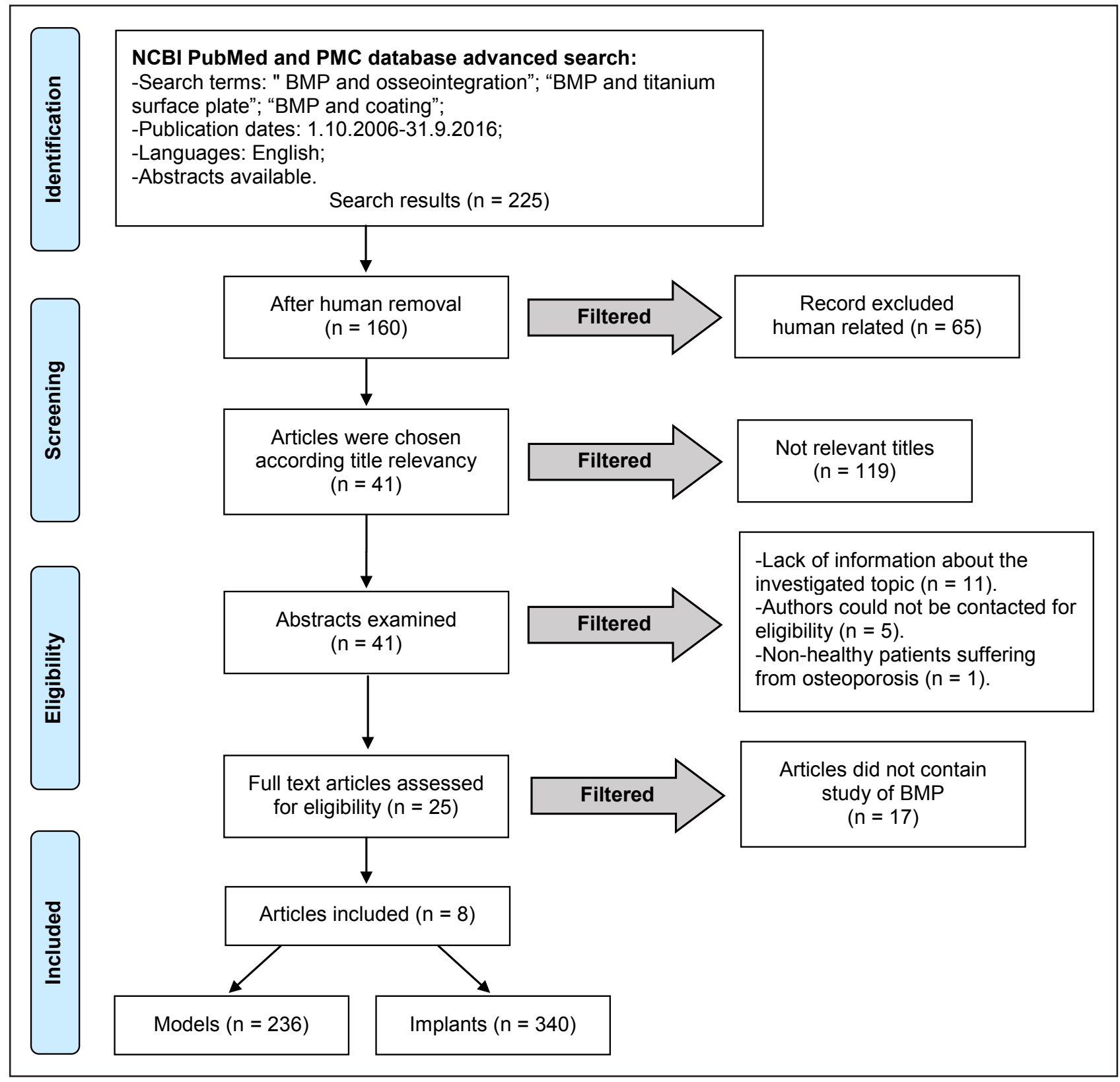

Figure 1. PRISMA flow diagram. 


\section{Study exclusion}

The reasons for excluding studies after full-text assessment were as follows: articles [19-29] that lack information about the investigated topic, articles [30$\underline{34]}$ with no full text available. Article [35] with nonhealthy patients.

\section{Quality assessment}

The results of risk of bias assessment (quality) for included article RCTs (random control trial) were summarized in Table 1. The result show that three $[1,2,2]$ studies were considered to have a low risk of bias while another five $[\underline{6}, \underline{7}, \underline{12}, \underline{14}, \underline{15}]$ were considered to have an unclear (unknown) risk of bias.

\section{Study characteristics}

In 2013, Jiang et al. [15] performed a study on 15 rabbits in order to evaluate if hBMP-2 which formed on sandblasted/roughened $\mathrm{Ti}$ implants will enhance bone formation in vivo. To determine the effect of BMP Jiang et al. [15] compared the roughed and sandblasted coated implants with uncoated control implants. Histomorphometric evaluation was applied after 2, 4 and 8 weeks and the result revealed that even though, BIC was higher for uncoated implants the amount of bone and cells cultured on coated surfaces sandblasted/roughened $\mathrm{Ti}$ implants had much higher cell viability than the control uncoated surfaces, furthermore, no difference was observed between 2 type of implant surfaces. They concluded that Ti implants coated with BMP-2 genes accelerated bone formation around the implants.

In 2014, Kim et al. [7] made an experimental analysis in vivo and in vitro to improve osteoblast function and bone formation in 3 examined dogs using heparin delivery method in order to immobilize BMP-2 to Ti implants surface. Four Ti implants were installed in each dog s mandible and maxilla in its left and right sides. ALP (alkaline phosphatase) activity, calcium deposition, and gene expression levels showed that, cells found on $\mathrm{Ti}$ implants containing BMP-2 can increase significantly the bone regeneration; this was in contrast to the case of implants without BMP-2. They also demonstrated that BMP-2/Heparin (Hep)$\mathrm{Ti}$ substrates significantly enhancing osteogenic differentiation compared to those of Ti substrates. The conclusion of this article is that BMP-2 stimulates early and late osteoblast differentiation.

However, there have been conflicting results with other articles found in current literature.

Lee et al. [12] compared peri-implant bone formation among different bone stimulating agent such as; HA, $\mathrm{CO}$ and HA, CO in combination with HA and BMP-2. Each group included 3 rabbits and in total 12 rabbits participated in the experiment and 24 implants were implanted in their tibia bone. Histomorphometric analysis was used to evaluate the bone formation results (Table 2). The results showed that HA and CO group gain greater peri-implant bone formation then with other stimulating agent.

Additionally, adding superficially adsorbed twodimensional BMP-2 to Ti implant surface did not show any advantage compared to HA and $\mathrm{CO}$ group, therefore they concluded that the addition of BMP-2 will not increase peri-implant bone formation and the mixture of $\mathrm{HA}$ and $\mathrm{Co}$ will display greater amount of new bone in compare to the other groups analysed in this study.

Mantripragada et al. [9] got also surprising results when used another isoform of BMP; BMP-7. The goal was to examine the bone repair after application of different delivery method on implants in defected femur of 80 rats.

Table 1. Bias summary

\begin{tabular}{l|c|c|c|c|c|c|c|c}
\hline \multicolumn{1}{c|}{ Study } & $\begin{array}{c}\text { Year of } \\
\text { publication }\end{array}$ & $\begin{array}{c}\text { Random } \\
\text { sequence } \\
\text { generation }\end{array}$ & $\begin{array}{c}\text { Allocation } \\
\text { concealment }\end{array}$ & $\begin{array}{c}\text { Blinding of } \\
\text { participant's } \\
\text { and personnel }\end{array}$ & $\begin{array}{c}\text { Blinding of } \\
\text { outcomes } \\
\text { assessment }\end{array}$ & $\begin{array}{c}\text { Incomplete } \\
\text { outcome } \\
\text { data }\end{array}$ & $\begin{array}{c}\text { Selective } \\
\text { reporting }\end{array}$ & $\begin{array}{c}\text { Other } \\
\text { bias }\end{array}$ \\
\hline Hunziker et al. [1] & 2012 & - & + & + & + & + & $?$ & + \\
\hline Sun et al. [2] & 2012 & - & + & + & + & + & + & + \\
\hline Xiao et al. [6] & 2016 & $?$ & + & + & + & + & + & $?$ \\
\hline Kim et al. [7] & 2014 & + & $?$ & $?$ & + & + & + & + \\
\hline Mantripragada et al. [9] & 2016 & + & $?$ & + & + & + & + & $?$ \\
\hline Lee et al. [12] & 2014 & $?$ & $?$ & + & + & + & $?$ & $?$ \\
\hline Bouyer et al. [14] & 2016 & + & $?$ & $?$ & + & + & + & + \\
\hline Jiang et al. [15] & 2013 & + & $?$ & $?$ & + & + & + & + \\
\hline
\end{tabular}

$+=$ low risk; $?=$ unclear risk; $-=$ high risk. 
Table 2. Characteristics of the included studies

\begin{tabular}{|c|c|c|c|c|c|c|c|c|c|}
\hline Study & Concentration & Carriage mode & BMP type & Model & $\begin{array}{c}\text { Bone formation } \\
\text { first week (\%) }\end{array}$ & \begin{tabular}{|c|} 
Bone formation \\
second week (\%)
\end{tabular} & $\begin{array}{l}\text { Bone formation } \\
\text { third week }(\%)\end{array}$ & $\begin{array}{c}\text { Bone formation } \\
\text { after }>4 \text { weeks }(\%)\end{array}$ & $\begin{array}{c}\text { Evaluation } \\
\text { method }\end{array}$ \\
\hline \multirow{4}{*}{$\begin{array}{l}\text { Hunziker et al. } \\
{[1]}\end{array}$} & $12.95 \mu \mathrm{g}$ & $\begin{array}{c}\text { Incorporated into } \\
\text { coating }\end{array}$ & \multirow{4}{*}{ BMP-2 } & \multirow{4}{*}{$\underset{\text { pigs }}{\text { Miniature }}$} & 60 & 83 & \multirow{2}{*}{$>90$} & \multirow{4}{*}{ NA } & \multirow{4}{*}{$\begin{array}{l}\text { Histomorpho- } \\
\text { metric }\end{array}$} \\
\hline & $\begin{array}{c}12.95 \mu \mathrm{g} \text { (incorporated) } \\
+10 \mu \mathrm{g} \text { (adsorbed) }\end{array}$ & $\begin{array}{l}\text { Incorporated into and } \\
\text { adsorbed onto coating }\end{array}$ & & & 74 & 83 & & & \\
\hline & \begin{tabular}{|l|}
$10 \mu \mathrm{g}$ \\
\end{tabular} & Adsorbed onto coating & & & 17 & 70 & \multirow[b]{2}{*}{75} & & \\
\hline & NA & Coating alone & & & 5 & 50 & & & \\
\hline \multirow{4}{*}{ Sun et al. [2] } & NA & NA & Control & \multirow{4}{*}{ Minipigs } & \multirow{4}{*}{ NA } & 6.04 & 20.55 & 27.88 & \multirow{4}{*}{$\begin{array}{l}\text { Histomorpho- } \\
\text { metric }\end{array}$} \\
\hline & \multirow{3}{*}{$\begin{array}{c}0.05 \mu \mathrm{g} / \mu \mathrm{L} 4 \mathrm{mM} \mathrm{HCl} \\
\text { solution containing } \\
\text { BSA } 0.1 \%\end{array}$} & \multirow{3}{*}{ Absorbable CO } & $\begin{array}{c}\text { rhBMP-2 } \\
\text { homodimers }\end{array}$ & & & 19.7 & 25.72 & 43.07 & \\
\hline & & & $\begin{array}{c}\text { rhBMP-7 } \\
\text { homodimers }\end{array}$ & & & 14.5 & 31.61 & 36.42 & \\
\hline & & & $\begin{array}{l}\text { rhBMP-2/7 } \\
\text { heterodimers }\end{array}$ & & & 30.41 & 40.72 & 59.44 & \\
\hline \multirow{3}{*}{ Xiao et al. [6] } & \multirow{3}{*}{$0.1 \mathrm{mg} / \mathrm{mL}$} & $\mathrm{AO}$ & \multirow{3}{*}{ rhBMP-2 } & \multirow{3}{*}{ Rabbits } & \multirow{3}{*}{ NA } & \multirow{3}{*}{ NA } & \multirow{3}{*}{ NA } & Lowest adsorption amount & \multirow{3}{*}{ Histologically } \\
\hline & & PT & & & & & & Better adsorption then $\mathrm{AO}$ & \\
\hline & & AA & & & & & & The great adsorption & \\
\hline \multirow{3}{*}{ Kim et al. [7] } & \multirow{2}{*}{$0.75 \mathrm{mg} / \mathrm{mL}$} & NA & & \multirow{3}{*}{ Dogs } & \multirow{3}{*}{ NA } & \multirow{3}{*}{ NA } & Vertical bone formation & \multirow{3}{*}{ NA } & \multirow{3}{*}{ Histologically } \\
\hline & & Heparin & BMP-2/Тi & & & & $\begin{array}{c}\text { Significantly greater } \\
\text { vertical bone formation }\end{array}$ & & \\
\hline & $\mathrm{NA}$ & NA & Control & & & & Failure of osseointegration & & \\
\hline & $7 \mathrm{mg}$ & & Microparticle & & & & & $6.41 \mathrm{NBF}(1 / \mathrm{mm})$ & \\
\hline Mantripragada et & 200 ng with PBS & Chitosan-TPP & $\begin{array}{l}\text { BMP-7 coated } \\
\text { microparticle }\end{array}$ & Rats & NA & NA & $\mathrm{NA}$ & $6.53 \mathrm{NBF}(1 / \mathrm{mm})$ & New bone \\
\hline al. [9] & NA & & $\begin{array}{c}\text { BMP-7 encapsulated } \\
\text { microparticle }\end{array}$ & Kals & NA & NA & NA & 4.89 NBF $(1 / \mathrm{mm})$ & $\begin{array}{l}\text { fragments } \\
(1 / \mathrm{mm})\end{array}$ \\
\hline & & NA & Control & & & & & $7.52 \mathrm{NBF}(1 / \mathrm{mm})$ & \\
\hline & & & HA & & & & & $22.85 \mathrm{NBF}, 24.18 \mathrm{BIC}$ & \\
\hline Lee et al. [12] & NA & $\mathrm{CP}$ & $\mathrm{HA} / \mathrm{Co}$ & Rabbits & NA & $\mathrm{NA}$ & NA & $47.04 \mathrm{NBF}, 41.45 \mathrm{BIC}$ & Histomorpho- \\
\hline Lectare $[12]$ & & & $\mathrm{HA} / \mathrm{CO} / \mathrm{BMP}-2$ & Navoris & NA & NA & NA & $21.72 \mathrm{NBF}, 30.72 \mathrm{BIC}$ & metric \\
\hline & & NA & Control & & & & & $23.34 \mathrm{NBF}, 21.38 \mathrm{BIC}$ & \\
\hline & $5 \mu \mathrm{g} / \mathrm{mL}$ & & & & & 0 & & & \\
\hline & $25 \mu \mathrm{g} / \mathrm{mL}$ & EDC-10 & & & & 62.5 & & & \\
\hline & $\begin{aligned} 50 \mu \mathrm{g} / \mathrm{mL} \\
100 \mu \mathrm{g} / \mathrm{mL}\end{aligned}$ & & & & & 100 & & & \\
\hline Bouyer et al. [14] & $\frac{100 \mu \mathrm{g} / \mathrm{mL}}{5 \mu \mathrm{gL}}$ & & BMP-2 & Rats & NA & 100 & NA & NA & Histomorpho- \\
\hline & $25 \mu \mathrm{g} / \mathrm{mL}$ & & & & & 50 & & & \\
\hline & $50 \mu \mathrm{g} / \mathrm{mL}$ & EDC-30 & & & & 100 & & & \\
\hline & $100 \mu \mathrm{g} / \mathrm{mL}$ & & & & & NA & & & \\
\hline Jiang et al. [15] & $\begin{array}{c}100 \mathrm{mg} \text { of EGFP-C1 } \\
\text { with } 5 \mathrm{mg} / \mathrm{ml}\end{array}$ & PEI & BMP-2 & Rabbits & NA & 37.4 & 31.7 & 41.5 & Histomorpho- \\
\hline & NA & NA & Control & & & 34.4 & 40.7 & 45.9 & \\
\hline
\end{tabular}

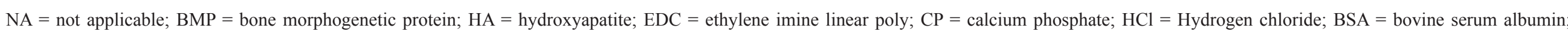
$\mathrm{AO}=$ anodic oxidation; $\mathrm{PT}=$ polished titanium; $\mathrm{AA}=$ acid alkali; $\mathrm{TPP}=$ sodium tri-polyphosphate; $\mathrm{BIC}=$ bone implant contact; $\mathrm{NBF}=$ new bone fragments. 
Chitosan-TPP and chitosan-TPP-BMP-7 scaffolds used as delivery method. Control group without any coating was also evaluated in their study for comparison. Histological and computerized tomography data showed that femoral defect around microparticle coated $\mathrm{Ti}$ implants was greater than the one in the control group. The control group presented with no complete healing. No significant difference was observed between microparticle with or without BMP-7. The factors that were suggested to influence the obtained results were:

- The fibrous capsule around microparticle which could have prevented the release of BMP.

- The quantity of BMP or the inflammatory process

BMP-2 and BMP-7 homodimers have been proven to be efficacious in accelerating bone formation in animal models; however its high cost, potential side effect and heterodimers were proposed to overcome those drawbacks [2].

Sun et al. [2] investigated the formation of new bone in peri-implant bone defect. Eighteen minipigs models were treated with same dose of $\mathrm{rhBMP} 2 / 7$ while different dimer was compared to homo/ hetero dimers. The result showed that the control group had no sufficient bone regeneration in compare to the test group which showed significant results, also after 6 weeks follow-up, bone regeneration with BMP-2 homodimer showed $43.07 \%$ while bone regeneration with BMP-7 homodimer showed $36.42 \%$. It was concluded that the use of BMP will result in better bone formation and BMP-2 has greater effect than BMP-7. The group of BMP-2/7 in their heterodimers form induced stronger bone regeneration than BMP2 and BMP-7 homodimers, by this they conclude that BMP-2/7 homodimers which are more expensive and have more risk for side effects, can be replaced with cheaper dimer as BMP-2/7 heterodimers for bone engineering with the same dose.

Bouyer at al. [14] made an experimental analysis in order to assess the effect of BMP-2 concentrations with EDC10 (ethylene imine linear poly) and EDC30 crosslinking levels. It was assessed while trying to fill volumetric femoral size defect. Comparison between BMP-2 in different concentrations was assessed with different delivery methods, as mentioned in Table 2. The BMP25 and BMP50 groups on EDC30 films exhibited similar levels to those of EDC10. It led them to conclude that EDC crosslinking levels have no significant influence on the bone volume ratio. The bone regeneration kinetics depended on the BMP-2 dose. The kinetics was extremely rapid for BMP50 and BMP100. However, encapsulated haematomas were found with these high doses of BMP-2.
They showed that better result will be presented with experimental group containing osteoinductive surface coating than control group and volume ratio increase with increasing BMP concentration. However, there was a direct correlation between increased bone volumes to higher chance for haematoma. To the best of our knowledge a several methods of local BMP delivery were proposed in the literature to enhance peri-implant osteogenesis.

In 2012, Hunziker et al. [1] compared the osteoinductive effectiveness of different modes of BMP-2 carriage within a defined osteoinductive space using the same experimental models. Ti Implants bore either a direct depot of BMP-2 or a coating adsorbed depot of BMP-2, a coating incorporated or a coating incorporated and a coating-adsorbed reservoir of the BMP-2, 6 implants with different coating were inserted into the maxillary bone of 18 pigs. The histomorphometric analysis evaluated the volume of newly formed bone 1, 2 and 3 weeks after surgery and revealed that the rate of this process is initially most rapid when the coating bore an adsorbed and an incorporated depot of BMP-2. Adsorbed group generate an initial high local concentration of BMP2 , but by the end of the third week, more than $90 \%$ of the coating had been degraded by activity of osteoclast and bone resorption appear.

Implants that bore a coating-incorporated depot of BMP-2 had a peak of osteogenic activity being attained during the first week and sustained thereafter. The osteoinductive efficacy index showed slightly lower for implants that bore a coating-adsorbed depot and lowest for implants that bore both a coating incorporated and a coating adsorbed BMP-2.

In three models inflammatory activity was noted adjacent to implant chamber.

Their findings demonstrate that the capacity of BMP-2 to induce local bone formation can be affected by its mode of delivery to the peri-implant space. Gradual liberation from a coated incorporated depot will present higher osteogenic response in compare to a rapid release from coating adsorbed depot.

It is well known that the change of the surface topography can affect the conformation of the adsorbed BMP-2 and normally, proteins tend to adsorb on the hydrophobic surface [6]

In 2016, Xiao et al. [6] made an experiment on 36 rabbits in order to investigate the mechanism of BMP2 functional change induced by modified Ti surface. They checked how different surface topography, polished $\mathrm{Ti}$ (PT) acid alkali (AA) and anodic oxidation (AO) can influence osteogenic function. Six Ti implants were implanted on both femurs while half of the implants were adsorbed with rhBMP-2. 
The evaluation performed in 2 methods; half of the participant subjected to push out test and the other half subjected to histological study.

The result revealed that adsorption amount of rhBMP-2 on AO treated implants was lowest while adsorption amount with AA treated implants was highest. PT group had the median adsorption amounts. They found also that structure is influenced by different surface topography. Even though largest amount of rhBMP-2 absorbed on AA and promoted osteogenic differentiation of mesenchymal stem cell (MSCs), this phenomenon didn't sustain for long time. On the other hand, AO treated implants which presented low adsorption amounts, retained for long term. It was also found that osteogenic function of BMP-2 is not only influenced by the concentration. But also on surface modification which can regulate structure of rhBMP-2 and can further influence its osteogenic function.

\section{DISCUSSION}

Autogenous bone has been the most popular for augmentation procedures based on the high success rate, though, the harvesting may require another surgical area with a result of high morbidity. Additionally, Triplett et al. [36] reported that the use of autogenous bone had greater prevalence of oedema, pain, sinusitis and erythema then BMP-2.

Since the eruption of BMP's in to the dental field, most of the research focus had been on the therapeutic application of specific BMP in regenerative therapy [37].

The purpose of this review was to investigate the osseointegration process affected by BMP coating on titanium implant surface as well as to find out the most efficient delivery system method and in the same time avoid adverse effects.

The result of current review demonstrated that the use of BMP-2 enhance bone regeneration, this statement was proved by Jiang et al. [15] study which presented much higher cell viability on hBMP-2 coated surfaces on sandblasted or roughened $\mathrm{Ti}$ implant than the uncontrolled surfaces, hence BMP-2 genes found to be important osteoinductive accelerators around $\mathrm{Ti}$ implants.

Additionally, Kim et al. [7] made an experimental analysis on mandible and maxilla of 3 examined dogs. The implants were also coated with BMP-2 and found to be valid in stimulation of early and late osteoblast differentiation. Bone regeneration was significantly increased around the coated implants in compare with the uncoated implants.
In current data, conflicting results were presented by different authors. Lee et al. [12] compared various bone stimulating agent as; HA, CO and BMP-2. It can be seen that greater peri-implant bone formation was formed with HA and $\mathrm{CO}$ group, while, with the peri-implant insertion of BMP bone didn't increase. Moreover, $\mathrm{HA}$ and $\mathrm{CO}$ will display in greater amount of new bone.

Mantripragada et al. [9] tried to examine bone repair follow application of BMP-7 by different delivery methods and no significant difference was observed between the comparable groups around coated $\mathrm{Ti}$ implants.

The factor that was suggested to influence the obtained results could be the fibrous capsule formed around microparticle which could have preclude the release of BMP and (1) affect the quantity of released BMP or (2) to result in inflammatory process, which can lead to increase in interleukins values resulting in (3) delay osseointegration, healing and bone formation.

To prevent these symptoms, anti-inflammatory medications may be prescribed [38]. Besides inflammatory response, following complications can develop with usage of BMPs: ectopic bone formation, osteoclast activity, cancer risk, pseudarthrosis, graft failure, swelling, infection, bleeding, oedema and erythema [37-39]. Moreover, in the current literature data on serious adverse effect was shown after the use of BMP-2 in oral and maxillofacial procedures resulting in additional surgical intervention and additional suffering for the patient. To deal with the adverse Tan et al. [40] suggested the use of systemic steroids in order to reduce soft tissue oedema that associated with BMP-2 application. Bouyer et al. [14] made an experiment in order to assess the effect the BMP2 in different concentrations and they found that the kinetics of bone regeneration was extremely rapid for BMP50/100 however encapsulated haematoma was found with those high doses. They revealed that better result will be present with osteoinductive surface but in lower concentrations. From this we can conclude that BMPs needs to be delivered to target sites gradually, at a low level and continuously, not in a single high dose burst. There are many methods suggested in literature for delivery of BMP to the target side $[\underline{1}, \underline{6}, \underline{7}]$. Attempts to use directly adsorbed BMPs to implant surface were made but with no success in osteoinductive efficacious [1]. Hunziker et al. [1] made an experiment to identify the osteoinductive efficacious with different modes of BMP-2 carriage within a defined osteoinductive space using the same experimental model. 
Their findings demonstrate that the capacity of BMP-2 to induce local bone formation can be affected by its mode of delivery to the peri-implant space and gradual liberation from a coated incorporated depot will present higher osteogenic response in compare to a rapid release from coating adsorbed depot BMPs.

The efficacy of BMP homodimers has been proved to be successful in many experiments. However, series of potential side effects and high costs resulted into a search for another dimer. Heterodimers were proposed to overcome these drawbacks. Heterodimer can induce cell migration with significant lower concentration needed which will be kept for longer period in a respect to homodimers. Sun et al. [2] investigated the formation of new bone in periimplant bone defect while comparing these 2 dimers. The results strengthen the use of heterodimers after they showed higher bone regeneration amount.

Ti implant surface topography may provide a way to regulate the function of BMP. Surface topography is the key factor for long term success rate of dental implant and successful osseointegration of Ti implant to bone tissue $[11, \underline{41}]$. Recently article was published by Xiao et al. [ $[6]$ in order to investigate how different surface topography can influence osteogenic function. They found that AA had the largest adsorption amount and suggested that osteogenic function is not only influenced by concentration however, surface modification has a big role on bone regeneration and osteoinduction.

Regulation of Ti implant surface topography may provide a way to regulate the function of BMP [6]. Yeo et al. [41] reported that acid etch topography has four times greater resistance to removal test, along with roughened sandblasted surface which was found to increase significantly bone contact. Both surfaces will have higher resistance to implant removal.

Certainly, BMPs have been used to promote osseointegration and bone regeneration as suggested by Yeo et al. [41], who reported that BMP coated on an oxidized $\mathrm{Ti}$ surface induced more bone osseointegration, regeneration and volume in compared with Ti oxidized layer who was luck in BMP coating [41].

By all authors topographically $\mathrm{Ti}$ implants surface reported to show high success rates and better result of osseointegration.

\section{CONCLUSIONS}

It's clearly shown from most of the examined studies that bone morphogenetic protein increases bone regeneration. Further studies should be done in order to induce and sustain bone formation activity. Osteogenic agent should be gradually liberated and not rapidly released with priority to threedimension reservoir (incorporated) titanium implant surface in order to avoid following severe side effects: inflammation, bleeding, haematoma, oedema, erythema, and graft failure.

\section{ACKNOWLEDGMENTS AND DISCLOSURE STATEMENTS}

The authors confirm that this review content has no conflict of interest with any financial organization regarding the material discussed in the review.

\section{REFERENCES}

1. Hunziker EB, Enggist L, Küffer A, Buser D, Liu Y. Osseointegration: the slow delivery of BMP-2 enhances osteoinductivity. Bone. 2012 Jul;51(1):98-106. [Medline: 22534475] [doi: 10.1016/j.bone.2012.04.004]

2. Sun P, Wang J, Zheng Y, Fan Y, Gu Z. BMP2/7 heterodimer is a stronger inducer of bone regeneration in peri-implant bone defects model than BMP2 or BMP7 homodimer. Dent Mater J. 2012;31(2):239-48. [Medline: 22447058] [doi: 10.4012/dmj.2011-191]

3. Shah NJ, Hyder MN, Moskowitz JS, Quadir MA, Morton SW, Seeherman HJ, Padera RF, Spector M, Hammond PT. Surface-mediated bone tissue morphogenesis from tunable nanolayered implant coatings. Sci Transl Med. 2013 Jun 26;5(191):191 ra83. [Medline: 23803705] [PMC free article: 4001255] [doi: 10.1016/j.carbpol.2013.05.095]

4. Zhang X, Zhang Z, Shen G, Zhao J. Enhanced osteogenic activity andanti-inflammatory properties of Lenti-BMP-2loaded $\mathrm{TiO}_{2}$ nanotube layers fabricated by lyophilization following trehalose addition. Int J Nanomedicine. 2016 Jan 25;11:429-39. [Medline: 26869786] [PMC free article: 4734802] [doi: 10.2147/IJN.S93177]

5. Lee SY, Yun YP, Song HR, Chun HJ, Yang DH, Park K, Kim SE. The effect of titanium with heparin/BMP-2 complex for improving osteoblast activity. Carbohydr Polym. 2013 Oct 15;98(1):546-54. [Medline: 23987380] [doi: $10.1016 /$ j.carbpol.2013.05.095]

6. Xiao M, Biao M, Chen Y, Xie M, Yang B. Regulating the osteogenic function of rhBMP 2 by different titanium surface properties. J Biomed Mater Res A. 2016 Aug;104(8):1882-93. [Medline: 26991341] [doi: 10.1002/jbm.a.35719] 
7. Kim SE, Kim CS, Yun YP, Yang DH, Park K, Kim SE, Jeong CM, Huh JB. Improving osteoblast functions and bone formation upon BMP-2 immobilization on titanium modified with heparin. Carbohydr Polym. 2014 Dec 19;114:123-32. [Medline: 25263872] [doi: 10.1016/j.carbpol.2014.08.005]

8. Yang DH, Lee DW, Kwon YD, Kim HJ, Chun HJ, Jang JW, Khang G. Surface modification of titanium with hydroxyapatiteheparin-BMP-2 enhances the efficacy of bone formation and osseointegration in vitro and in vivo. J Tissue Eng Regen Med. 2015 Sep;9(9):1067-77. [Medline: 25524250] [doi: 10.1002/term.1973]

9. Mantripragada VP, Jayasuriya AC. Bone regeneration using injectable BMP-7 loaded chitosan microparticles in rat femoral defect. Mater Sci Eng C Mater Biol Appl. 2016 Jun;63:596-608. [Medline: 27040255] [PMC free article: 4839977] [doi: $10.1016 /$ j.msec.2016.02.080]

10. Wu G, Hunziker EB, Zheng Y, Wismeijer D, Liu Y. Functionalization of deproteinized bovine bone with a coatingincorporated depot of BMP-2 renders the material efficiently osteoinductive and suppresses foreign-body reactivity. Bone. 2011 Dec;49(6):1323-30. [Medline: 21983022] [doi: 10.1016/j.bone.2011.09.046]

11. Dolanmaz D, Saglam M, Inan O, Dundar N, Alniacık G, Gursoy Trak B, Kocak E, Hakki SS. Monitoring bone morphogenetic protein-2 and -7 , soluble receptor activator of nuclear factor- $\kappa \mathrm{B}$ ligand and osteoprotegerin levels in the peri-implant sulcular fluid during the osseointegration of hydrophilic-modified sandblasted acid-etched and sandblasted acid-etched surface dental implants. J Periodontal Res. 2015 Feb;50(1):62-73. [Medline: 24697526] [doi: $10.1111 /$ jre. 12182]

12. Lee SW, Hahn BD, Kang TY, Lee MJ, Choi JY, Kim MK, Kim SG. Hydroxyapatite and collagen combination-coated dental implants display better bone formation in the peri-implant area than the same combination plus bone morphogenetic protein-2-coated implants, hydroxyapatite only coated implants, and uncoated implants. J Oral Maxillofac Surg. 2014 Jan;72(1):53-60. [Medline: 24331565] [doi: 10.1016/i.joms.2013.08.031]

13. Ramazanoglu M, Lutz R, Rusche P, Trabzon L, Kose GT, Prechtl C, Schlegel KA. Bone response to biomimetic implants delivering BMP-2 and VEGF: an immunohistochemical study. J Craniomaxillofac Surg. 2013 Dec;41(8):826-35. [Medline: 23434516] [doi: 10.1016/i.jcms.2013.01.037]

14. Bouyer M, Guillot R, Lavaud J, Plettinx C, Olivier C, Curry V, Boutonnat J, Coll JL, Peyrin F, Josserand V, Bettega G, Picart C. Surface delivery of tunable doses of BMP-2 from an adaptable polymeric scaffold induces volumetric bone regeneration. Biomaterials. 2016 Oct;104:168-81. [Medline: 27454063] [doi: 10.1016/j.biomaterials.2016.06.001]

15. Jiang QH, Liu L, Peel S, Yang GL, Zhao SF, He FM. Bone response to the multilayer BMP-2 gene coated porous titanium implant surface. Clin Oral Implants Res. 2013 Aug;24(8):853-61. [Medline: 22168601] [doi: $10.1111 / \mathrm{j} .1600-0501.2011 .02383 . \mathrm{x}]$

16. Chien PF, Khan KS, Siassakos D. Registration of systematic reviews: PROSPERO. BJOG. 2012 Jul;119(8):903-5. [Medline: 22703418] [doi: 10.1111/j.1471-0528.2011.03242.x]

17. Moher D, Liberati A, Tetzlaff J, Altman DG; PRISMA Group. Preferred reporting items for systematic reviews and meta-analyses: the PRISMA statement. Int J Surg. 2010;8(5):336-41. Erratum in: Int J Surg. 2010;8(8):658. [Medline: 20171303] [doi: 10.1016/j.ijsu.2010.02.007]

18. Higgins JPT, Green S. Cochrane Handbook for Systematic Reviews of Interventions. [URL: http://www.cochrane.org/cochrane-interventions-handbook]

19. Lehmann LJ, Werner A, Dinter DJ, Mauermann E, Seidling R, Brade J, Laub M, Luers S, Madenci S, Jennissen H, Obertacke U, Scharf HP, Schwarz ML. Scintigraphic evaluation of rhBMP-2-biocoated implants reveals no ectopic bone formation. Biomed Pharmacother. 2011 Feb;65(1):63-8. [Medline: 21177064] [doi: 10.1016/i.biopha.2010.10.008]

20. Lin GH, Lim G, Chan HL, Giannobile WV, Wang HL. Recombinant human bone morphogenetic protein 2 outcomes for maxillary sinus floor augmentation: a systematic review and meta-analysis. Clin Oral Implants Res. 2016 Nov;27(11):13491359. [Medline: 26620161] [doi: 10.1111/clr.12737]

21. Froum SJ, Wallace S, Cho SC, Khouly I, Rosenberg E, Corby P, Froum S, Mascarenhas P, Tarnow DP. Radiographic comparison of different concentrations of recombinant human bone morphogenetic protein with allogenic bone compared with the use of $100 \%$ mineralized cancellous bone allograft in maxillary sinus grafting. Int J Periodontics Restorative Dent. 2014 Sep-Oct;34(5):611-20. [Medline: 25171031] [doi: 10.11607/prd.2037]

22. Pfeifer CG, Karl A, Berner A, Zellner J, Schmitz P, Loibl M, Koch M, Angele P, Nerlich M, Mueller MB. Expression of BMP and Actin Membrane Bound Inhibitor Is Increased during Terminal Differentiation of MSCs. Stem Cells Int. 2016;2016:2685147. [Medline: 27843458] [PMC free article: 5097819]

23. Hussain T, Schneider M, Summer B, Strieth S. Pre-operative in vitro fibroblast coating of porous polyethylene compound grafts - Cell survival in vivo and effects on biocompatibility. Biomed Mater Eng. 2016 Aug 12;27(2-3):237-49. [Medline: 27567778] [doi: 10.3233/BME-161579]

24. Hyzy SL, Olivares-Navarrete R, Hutton DL, Tan C, Boyan BD, Schwartz Z. Microstructured titanium regulates interleukin production by osteoblasts, an effect modulated by exogenous BMP-2. Acta Biomater. 2013 Mar;9(3):5821-9. [Medline: 23123301] [PMC free article: 3618455] [doi: 10.1016/j.actbio.2012.10.030]

25. Lee DW, Yun YP, Park K, Kim SE. Gentamicin and bone morphogenic protein-2 (BMP-2)-delivering heparinized-titanium implant with enhanced antibacterial activity and osteointegration. Bone. 2012 Apr;50(4):974-82. [Medline: 22289658] [doi: 10.1016/j.bone.2012.01.007] 
26. Sun W, Zhang G, Tan L, Yang K, Ai H. The fluoride coated AZ31B magnesium alloy improves corrosion resistance and stimulates bone formation in rabbit model. Mater Sci Eng C Mater Biol Appl. 2016 Jun;63:506-11. [Medline: 27040245] [doi: 10.1016/j.msec.2016.03.016]

27. Schwarting T, Schenk D, Frink M, Benölken M, Steindor F, Oswald M, Ruchholtz S, Lechler P. Stimulation with bone morphogenetic protein-2 (BMP-2) enhances bone-tendon integration in vitro. Connect Tissue Res. 2016;57(2):99-112. [Medline: 26558768] [doi: 10.3109/03008207.2015.1087516]

28. Jung HD, Jang TS, Wang L, Kim HE, Koh YH, Song J. Novel strategy for mechanically tunable and bioactive metal implants. Biomaterials. 2015 Jan;37:49-61. [Medline: 25453937] [doi: 10.1016/j.biomaterials.2014.10.027]

29. Park SY, Kim KH, Gwak EH, Rhee SH, Lee JC, Shin SY, Koo KT, Lee YM, Seol YJ. Ex vivo bone morphogenetic protein 2 gene delivery using periodontal ligament stem cells for enhanced re-osseointegration in the regenerative treatment of peri-implantitis. J Biomed Mater Res A. 2015 Jan;103(1):38-47. [Medline: 24616330] [doi: 10.1002/jbm.a.35145]

30. Jennissen HP. Accelerated and improved osteointegration of implants biocoated with bone morphogenetic protein 2 (BMP-2). Ann N Y Acad Sci. 2002 Jun;961:139-42. [Medline: 12081883] [doi: 10.1111/j.1749-6632.2002.tb03067.x]

31. Zheng Y, Wu G, Zhao J, Wang L, Sun P, Gu Z. rhBMP2/7 heterodimer: an osteoblastogenesis inducer of not higher potency but lower effective concentration compared with rhBMP2 and rhBMP7 homodimers. Tissue Eng Part A. 2010 Mar;16(3):879-87. [Medline: 19814588] [doi: 10.1089/ten.tea.2009.0312]

32. Lan J, Wang ZF, Shi B, Xia HB, Cheng XR. The influence of recombinant human BMP-2 on bone-implant osseointegration: biomechanical testing and histomorphometric analysis. Int J Oral Maxillofac Surg. 2007 Apr;36(4):345-9. [Medline: 17300917] [doi: 10.1016/j.ijom.2006.10.019]

33. Sharmin F, McDermott C, Lieberman J, Sanjay A, Khan Y. Dual growth factor delivery from biofunctionalized allografts: Sequential VEGF and BMP-2 release to stimulate allograft remodeling. J Orthop Res. 2017 May;35(5):1086-1095. [Medline: 27155087] [doi: 10.1002/jor.23287]

34. Ventura M, Sun Y, Cremers S, Borm P, Birgani ZT, Habibovic P, Heerschap A, van der Kraan PM, Jansen JA, Walboomers $\mathrm{XF}$. A theranostic agent to enhance osteogenic and magnetic resonance imaging properties of calcium phosphate cements. Biomaterials. 2014 Feb;35(7):2227-33. [Medline: 24342727] [doi: 10.1016/j.biomaterials.2013.11.084]

35. Wölfle JV, Fiedler J, Dürselen L, Reichert J, Scharnweber D, Förster A, Schwenzer B, Reichel H, Ignatius A, Brenner RE. Improved anchorage of Ti6Al4V orthopaedic bone implants through oligonucleotide mediated immobilization of BMP-2 in osteoporotic rats. PLoS One. 2014 Jan 21;9(1):e86151. [Medline: 24465929] [PMC free article: $\underline{3897651]}$ [doi: 10.1371/journal.pone.0086151]

36. Triplett RG, Nevins M, Marx RE, Spagnoli DB, Oates TW, Moy PK, Boyne PJ. Pivotal, randomized, parallel evaluation of recombinant human bone morphogenetic protein-2/absorbable collagen sponge and autogenous bone graft for maxillary sinus floor augmentation. J Oral Maxillofac Surg. 2009 Sep;67(9):1947-60. [Medline: 19686934] [doi: 10.1016/j.joms.2009.04.085]

37. Lin GH, Lim G, Chan HL, Giannobile WV, Wang HL. Recombinant human bone morphogenetic protein 2 outcomes for maxillary sinus floor augmentation: a systematic review and meta-analysis. Clin Oral Implants Res. 2016 Nov;27(11):13491359. [Medline: 26620161] [doi: 10.1111/clr.12737]

38. Woo EJ. Adverse events reported after the use of recombinant human bone morphogenetic protein 2. J Oral Maxillofac Surg. 2012 Apr;70(4):765-7. [Medline: 22177811] [doi: 10.1016/j.joms.2011.09.008]

39. Kim HJ, Chung JH, Shin SY, Shin SI, Kye SB, Kim NK, Kwon TG, Paeng JY, Kim JW, Oh OH, Kook MS, Yang HJ, Hwang SJ. Efficacy of rhBMP-2/Hydroxyapatite on Sinus Floor Augmentation: A Multicenter, Randomized Controlled Clinical Trial. J Dent Res. 2015 Sep;94(9 Suppl):158S-65S. [Medline: 26185033] [doi: 10.1177/0022034515594573]

40. Tan Y, Montgomery SR, Aghdasi BG, Inoue H, Kaner T, Tian H, Terrell R, Zhang X, Wang JC, Daubs MD. The effect of corticosteroid administration on soft-tissue inflammation associated with rhBMP-2 use in a rodent model of inflammation. Spine (Phila Pa 1976). 2013 May 1;38(10):806-13. [Medline: 23197010] [doi: 10.1097/BRS.0b013e31827eca09]

41. Yeo IS. Reality of dental implant surface modification: a short literature review. Open Biomed Eng J. 2014 Oct 31;8: 114-9. [Medline: 25400716] [PMC free article: 4231373] [doi: 10.2174/1874120701408010114]

\section{To cite this article:}

Haimov H, Yosupov N, Pinchasov G, Juodzbalys G.

Bone Morphogenetic Protein Coating on Titanium Implant Surface: a Systematic Review

J Oral Maxillofac Res 2017;8(2):e1

URL: http://www.ejomr.org/JOMR/archives/2017/2/e1/v8n2e1.pdf

doi: $10.5037 /$ jomr.2017.8201 
Copyright $@$ C Haimov H, Yosupov N, Pinchasov G, Juodzbalys G. Published in the JOURNAL OF ORAL \& MAXILLOFACIAL RESEARCH (http://www.ejomr.org), 30 June 2017.

This is an open-access article, first published in the JOURNAL OF ORAL \& MAXILLOFACIAL RESEARCH, distributed under the terms of the Creative Commons Attribution-Noncommercial-No Derivative Works 3.0 Unported License, which permits unrestricted non-commercial use, distribution, and reproduction in any medium, provided the original work and is properly cited. The copyright, license information and link to the original publication on (http://www.ejomr.org) must be included. 